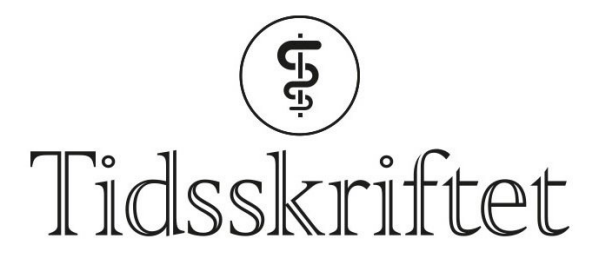

DEN NORSKE LEGEFORENING

\title{
Ikke kirurgi ved skuldersmerter
}

FRA ANDRE TIDSSKRIFTER

KETIL SLAGSTAD

Tidsskriftet

Pasienter med subakromialt smertesyndrom bør som hovedregel ikke tilbys operasjon. Det viser en ny studie.

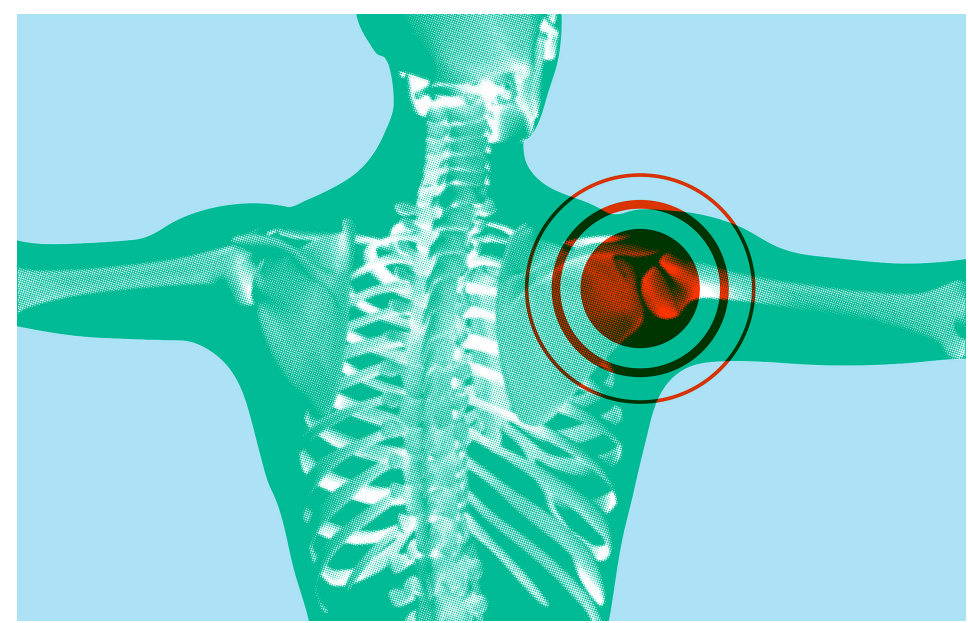

Illustrasjonsfoto: iMrSquid/iStock.

I en studie publisert i tidsskriftet BMJ ble 210 pasienter med subakromialt smertesyndrom i skulder randomisert til enten artroskopisk subakromial dekompresjon, artroskopi uten kirurgi (narrekirurgi) eller treningsopplegg i regi av fysioterapeut (1). Pasientene var 35-65 år, hadde hatt smerter i minst tre måneder og intakte rotatormansjettsener verifisert med MR.

Etter to år hadde alle gruppene mindre skuldersmerte i hvile og aktivitet, men det var ingen statistisk signifikant forskjell i skuldersmerter eller -funksjon mellom gruppene som fikk kirurgi og narrekirurgi. Gruppen som fikk kirurgi hadde en liten statistisk signifikant bedring av VAS-skår sammenlignet med treningsgruppen, men forskjellen ble bedømt til ikke å være klinisk relevant. Manglende blinding av treningsgruppen var en viktig konfunderende faktor som kan ha gitt kirurgigruppen en fordel. Studiens funn er sammenfallende med en annen studie som nylig ble omtalt i Tidsskriftet (2).

- Dette er en viktig studie, særlig siden inklusjonskriteriene var så strenge. Kun pasienter man forventet ville ha god nytte av kirurgi, ble inkludert. Pasienter med skader i rotatormansjetten, instabiliteter, artrose i akromioklavikulær- eller glenohumeralledd og smerter utstrålende fra nakken ble ekskludert, sier Bernd Günter Wünsche, som er overlege i ortopedi ved St. Olavs hospital. - Subakromiale smerter er vanlige hos personer over 40 år, 
og operasjoner der man fjerner ben fra akromion økte betydelig i mange vestlige land i perioden 2000-15. Økt brukt av narrekirurgi i ortopedisk forskning er et gode, siden vi vet at operasjoner i seg selv gir en betydelig placeboeffekt og fordi noen tilstander blir bedre av seg selv. Det foreligger nå flere gode studier som gjør at vi kan stille spørsmål ved nytten av kirurgisk behandling ved subakromialt smertesyndrom, sier Wünsche.

\section{LITTERATUR:}

1. Paavola M, Malmivaara A, Taimela S et al. Subacromial decompression versus diagnostic arthroscopy for shoulder impingement: randomised, placebo surgery controlled clinical trial. BMJ 2018; 362: k286o. [PubMed][CrossRef]

2. Sivertsen $\emptyset$ S. Ingen effekt av kirurgi ved skuldersmerter. Tidsskr Nor Legeforen 2018; 138. doi: 10.4045/tidsskr.18.0197. [PubMed][CrossRef]

Publisert: 12. oktober 2018. Tidsskr Nor Legeforen. DOI: 10.4045/tidsskr.18.0648

(C) Tidsskrift for Den norske legeforening 2020. Lastet ned fra tidsskriftet.no 